\title{
Cost-effectiveness analysis \\ of the New South Wales Adult Drug Court Program
}

\author{
Marian Shanahan ${ }^{1,2}$, Emily Lancsar ${ }^{1}$, Marion Haas ${ }^{1}$ Bronwyn Lind ${ }^{3}$ Don \\ Weatherburn ${ }^{3}$ Shuling Chen ${ }^{3}$
}

\begin{abstract}
Affiliations
${ }^{1}$ Centre for Health Economics Research and Evaluation, University of Technology Sydney, NSW, Australia

${ }^{2}$ National Drug and Alcohol Research Centre, University of New South Wales, Sydney, NSW, Australia

${ }^{3}$ NSW Bureau of Crime Statistics and Research, Sydney, NSW, Australia
\end{abstract}

\section{Corresponding author and reprint requests}

Marian Shanahan

National Drug and Alcohol Research Centre

University of New South Wales, Sydney NSW 2052, Australia

(email: m.shanahan@unsw.edu.au)

Telephone: ISD+61+2+9385-0333

Facsimile: ISD+61+2+9385-0222

Word count: 4825 
Cost-effectiveness analysis of

\section{the New South Wales Adult Drug Court \\ Program}




\begin{abstract}
(97 words- has to be less than 100)

In New South Wales, Australia, a cost effectiveness evaluation was conducted of an adult drug court program as an alternative to jail for the increasing number of criminal offenders addicted to illicit drugs. This paper describes the program, the CEA and the results. While the evaluation was conducted using the traditional steps of a CEA, due to the complexity of the program and data limitations it was not always possible to adhere to 'text book procedures'. This paper discusses each of the steps involved in undertaking the CEA highlighting the key issues faced in the evaluation.
\end{abstract}




\section{Introduction}

Drug Courts emerged as a response to the rapid growth in arrests and build up in court backlogs which followed the American "War on Drugs". The rapid growth in prisoner numbers coincided with rising bureaucratic and political scepticism about the effectiveness of prison in dealing with drug offenders ${ }^{(1)}$. The first drug court was established in Dade County Florida in 1989 and by 1994 there were 421 drug courts operating the US. By the end of 1995 that figure had doubled ${ }^{(2)}$.

Compared with other legally imposed sanctions, drug court programs are a form of 'coerced treatment'. The "treatment" is usually implemented by a team of people led by a judge and includes the defendant's legal representative as well as representatives from the prosecution, probation and treatment services ${ }^{(3,4)}$.

The literature on the cost effectiveness of drug courts is limited. While some studies have investigated the outcomes and costs associated with drug courts, prior to this study, no full cost effectiveness analysis of a drug court relative to usual treatment was found in the literature.

In terms of effectiveness, the evidence is mixed. A number of evaluations of the effectiveness of drug courts have been conducted. While the results of some studies ${ }^{(5-}$ 7, 8.) provide evidence that drug court programs can be effective in reducing drugrelated crime, others obtain different results. In two reviews by Belenko ${ }^{(9,10)}$ of the evidence on effectiveness of drug courts it was concluded that drug courts are effective in reducing drug use and criminal behaviour while participants remain on the program $^{(10)}$ but also noted that many evaluations of drug courts were marred by serious methodological weaknesses ${ }^{(11)}$. 
Belenko also appraised studies which report costs ${ }^{(11)}$. Although overall, the results suggest that in the US it may be less expensive to deal with offenders by using a drug court regime rather than conventional sanctions, Blenko again notes a number of methodological concerns with these studies. Moreover, the results are of limited value in the Australian context: Australian courts are generally less punitive than US courts in response to drug and drug-related offences and, whereas most drug court treatment regimes in the US are abstinence-based, the NSW ADC makes substantial use of pharmacotherapies such as methadone maintenance treatment, which have been shown to be successful in reducing recidivism by drug-dependent offenders ${ }^{(3)}$.

This paper describes the economic evaluation of the New South Wales (NSW) Adult Drug Court (ADC) program which was the first drug court program set up in Australia. Since the program discussed here was set up, other programs have been set up in four other States in Australia ${ }^{(12,13)}$.

\section{Description of NSW Drug Court Trial}

The NSW ADC program was an initiative of the NSW Government to divert drug using offenders from the traditional criminal justice system ${ }^{(14)}$. The goal of the ADC was to decrease the level of criminal activity that results from drug dependency by diverting offenders into programs designed to reduce or eliminate drug dependence using a combination of close supervision and therapeutic treatment ${ }^{(15)}$.

The program was implemented using new legislation, the Drug Court Act 1998. The Act was passed on the condition that the program be evaluated, part of which included a randomised control trial. Individuals were referred to the ADC by either a magistrate or judge to be assessed for suitability. The criteria for acceptance are described in Table 1. 
The process through the trial is depicted in Figure 1: If, after an individual was deemed suitable for the ADC program, a place was available in a detoxification program, the applicant was accepted into the program. If there were more suitable people than there were beds available, a randomization process occurred. Those who were deemed suitable, but for whom no detoxification bed was available, became part of the control group.

Individuals allocated to the control group were sent back to the referring court and were dealt with by the normal judicial process. The treatment group received a complete assessment of their therapeutic needs while undergoing detoxification. Once the detoxification was completed and if the individual was willing and able to continue treatment, they appeared before the ADC, pleaded guilty, and received a sentence which was suspended while they participated in the ADC program.

Once on the ADC program participants were to move through three stages of the program over a twelve-month period with the level of supervision diminishing at each stage. Participants received treatment for their addiction (methadone, buprenorphine, naltrexone or residential rehabilitation were the most common), attended counselling and relapse prevention training, liaised with the probation and parole service, attended the ADC on a regular basis and underwent random urine drug screening tests. If a participant failed to comply with the ADC rules they were sanctioned, resulting in a period of incarceration (usually seven to fourteen days). If an individual continued to fail to comply, his or her involvement in the ADC could be terminated. If this occurred, the original sentence was reviewed and most were incarcerated for the remainder of their sentence ${ }^{(4)}$. 


\section{Methods}

The cost effectiveness analysis was designed to investigate whether the NSW ADC program was a cost effective method of decreasing recidivism rates relative to the conventional court program. The perspective of this study was that of the treatment provider, where the 'treatment' was the drug court program or the conventional court system. The evaluation covered the period from the inception of the NSW ADC program in February 1999 through to December 2000. Subjects included in the analysis are those who entered the study prior to 30 June 2000. The original goal of the evaluation was to monitor participants over one year of treatment and six months post treatment. However, the program did not operate as expected, with some participants remaining in the first stage for many months. Others progressed to stage two and then re-entered stage one before advancing again. Many participants stayed in the program for more than two years. A number of individuals were either terminated from the program by the court or left voluntarily.

\section{Outcomes}

Two measures of effectiveness were examined, both relating to offences committed during the follow-up period. These were the time to the first offence and offending frequency per unit time. Both were calculated for each type of offence considered. Since the aim of the ADC is to reduce drug-related crime, theft offences and drug offences were the only offence types examined in this study. The theft offences examined were break, enter and steal; fraud; larceny by shop-stealing; other larceny; unlawful possession; and motor vehicle theft. The drug offences examined were possess/use opiates; possess/use cannabis; possess/use other drug; and deal/traffic opiates. In addition an aggregate theft offence (being a theft offence of any of the 
specified types) and an aggregate drug offence (being a drug offence of any of the specified types) were examined.

The specific theft offence used in the cost-effectiveness analysis was shop-stealing and the drug offence was possess/use opiates. These offences were chosen first, because they are reasonable marker offences for the drug-related offences which the ADC program is targeted at reducing and second, because there were significant differences in effectiveness for these two offences (for one of the effectiveness measures).

Most of the control group and many of the treatment subjects spent time in custody during the study. Because there is no opportunity for a person to offend while incarcerated, for the purpose of the CEA we used 'free time' that is, time out of custody. (Measures based on total elapsed time were also analysed; see Lind, Weatherburn, Chen et al. $2002^{(4)}$. Thus the analysis provides a direct comparison of the treatment and control groups assuming they have equal opportunities to offend.

\section{Sources of data}

Three sources of data were used for the effectiveness part of the study. The primary source, the ADC database, contained information on sex, date of birth, previous imprisonment and prior conviction episodes.

Time spent in custody was determined from data provided by the NSW Department of Corrective Services. Personal identifying details from the ADC database were matched with these records to provide dates of entry and exit from gaol for every episode of imprisonment for the matched individuals. Data on offences committed during the follow-up period were drawn from the database of criminal matters dealt with by the NSW Local Court and from a database maintained by the NSW Bureau of 
Crime Statistics and Research database for offences committed during the follow-up period.

Some offences may have been dealt with in the NSW District Court rather than the Local Court. However, it was not feasible to use this data source, firstly because many months can elapse before a matter is finalised in the District Court and, secondly, because date of offence is not recorded in the District Court database. At least 95 per cent of criminal prosecutions in NSW are dealt with in the Local Court. Hence the impact of excluding offences dealt with in the District Court is likely to be negligible.

\section{Calculation of effectiveness measures}

The measures of effectiveness were the time to the first offence and offending frequency per unit time, both based on the time spent out of custody in the follow-up period for each subject. Survival analysis techniques were used to analyse the time to first offence because the data were censored (that is, a person may not have committed an offence by the end of the follow-up period) and because the follow-up periods were of different durations for each person. Kaplan-Meier survival functions for the treated and control groups were compared for each type of offence. The survival functions plot the proportion of the sample 'surviving', that is, the proportion who had not yet committed an offence of the specified type, against the number of days in the follow-up period. In each case a log-rank test was conducted to test the hypothesis of equality of the two survival functions.

Offending frequency was measured as the number of offences per unit time. Because the numbers of offences were small, the time unit was set at 365 days, so that the frequency measures became offences per 'year'. The Wilcoxon two-sample test was 
used to test for differences in offending frequency between the treated and control groups.

\section{Costing}

The NSW ADC program is a complex intervention, involving a number of government agencies, types and stages of treatment. The approach in this evaluation follows standard costing techniques used for economic evaluations: identify the activities to be costed, identify the resources used in those activities, measure in physical units the volume of resources used, and finally apply a standard unit cost to those resources to estimate a value of resource use.

A total cost for each individual was obtained by summing over the estimated component costs as follows.

Total cost per person $=$

(Average Assessment costs)+(Average cost of court appearance *number of court appearances $)+($ Average cost of treatment *days in treatment) +Average cost of urine screen * urine samples)+(Average cost of probation and parole * days $)+($ Penalty per diem * days $)$.

A grand total cost for the treatment and control groups was reached by summing over the total cost for each individual. Finally, an average cost per day was calculated for both the treatment and control groups by dividing the total costs by total number of days.

Average cost per day on program $=$ Total cost/total days on the program

\section{Treatment Group Costs}

Staff from each of the agencies involved were interviewed from which a list of broad areas of activity each with several sub-categories was drawn up (see Table 2).

-Insert Table 2 about here - 
NSW Adult Drug Court - Expenditures on the court itself included all salaries and on costs for team members (judges, public prosecutor, legal aid, corrections health, probation and parole, registry staff, court reporter, security staff and court attendant), overheads, supplies, rental costs and estimates of corporate overheads from the various departments.

Using information from staff surveys, the proportion of team members' activities which related to team meetings or court activities was estimated, (see Table 3 Error! Reference source not found.). These proportions were used to estimate the direct costs related to court time and team meetings. The costs were apportioned over the total number of Court appearances during the same period (each type of appearance was weighted by the average number of minutes it usually took as per Table 4). Information from the staff surveys was also used to estimate the time team members spent managing participant related aspects of the ADC outside of the court setting. Overhead costs were apportioned equally across the total number of drug court appearances. Finally, the components were summed to obtain an average cost for each type of appearance.

- Insert Table 3 about here-

-Insert Table 4 about here -

Detoxification/ treatment planning - Initial detoxification and treatment planning occurred in gaol. Using data from Corrections Health Service (CHS) for the men's gaol plus the marginal daily cost for the facility itself, the cost per day of stay in the detoxification unit was estimated by combining the cost of detoxification obtained 
from Corrections Health Service with the cost of a day in gaol for both males and females. These daily costs were then multiplied by the time spent by each participant in detoxification.

Addiction Treatment costs -Treatment for heroin addiction was provided by one of three Area Health Services near the NSW Adult Drug Court and by residential rehabilitation centres. As in other key areas, all appropriate financial data on the provision of ADC were obtained including any overhead departmental expenses. The costs of providing treatment plus the residential rehabilitation costs for each year were summed and apportioned across all available days for treatment in each year. Individual costs were estimated by multiplying days available for treatment by the average cost.

Urine Screens - Random urine screens for illicit substances were an important component of the ADC program. The number of urine drug screening tests, by participant, which were sent to a laboratory for testing were obtained from the ADC database. However, the actual cost of each test was unknown. Thus, the total reported expenditure on urine drug screening tests was combined with the total number of screens undertaken to obtain an average cost of \$18.36 per test. This cost was then applied to each urine test reported by the laboratory.

Department of Corrective Services - Participants used the resources of the Department of Corrective Services at many points in the program including time in gaol at point of assessment, detoxification, sanctions, time in gaol if terminated from the program, home detention, and probation and parole. Resource use by the individual was not available for the Department of Corrective Services; therefore cost per inmate per day provided by the department for each of the three main correctional facilities was used for time incarcerated and sanctions. In addition, cost of transporting participants to 
and from the Court for sanctions or hearings was included. The cost per day was multiplied by the number of days incarcerated either as a sentence following a subsequent arrest while still on the program, termination from the program, or as a result of sanctions.

Probation and parole - Probation and parole were part of the assessment, treatment and monitoring of the participants in the ADC program. Financial data were available for salaries, overheads, and supplies for each of the years of the ADC program. These costs were apportioned across participants based on the number of days they spent in the ADC program.

\section{Control Group Costs}

The resources expended on the control group can be separated into three components: assessment for eligibility into the ADC; sentencing within the conventional court system; and imposition of a penalty. While assessment costs were calculated using the same method as used for the treatment group, sentencing costs were calculated in a different manner. One hundred and nine of the control group were sentenced in a Local Court while 29 were sentenced in a District Court. Direct and indirect costs for each type of court were calculated separately. Direct costs are those related to the sentencing, primarily salary costs of the Registry staff, Magistrate, court attendant and monitor, legal aid and police prosecutor. Indirect costs such as corporate overheads and other operating costs are incurred by the system but are not directly related to any one case. To calculate the direct costs: the activities involved in sentencing an average case were identified (broken into those that occur prior to, during and after a court appearance), as was the level of personnel who performed these tasks and their salaries; the time taken to perform these activities was estimated and finally the 
activities were valued using the appropriate salaries. This produced a direct cost per minute of staff time broken down by staff classification.

Local Court overheads and other operating expenses were apportioned over the registry staff to obtain an overhead cost per Registry staff per minute. This indirect cost was combined with the per-minute direct cost to obtain an overall cost per minute by staff classification level. This was multiplied by the number of minutes spent on a selection of representative sentencing cases to obtain a cost per sentence in a local court.

As similar data were not available for District Courts, the average cost per sentence in a District Court was calculated using the ratio of the cost of a day in a Local and District Court. This ratio, provided by the Attorney General’s Department, was calculated to be 1: 1.6. Thus the cost per sentence in a Local Court was multiplied by 1.6 to obtain a cost per sentence in a District Court. Matters dealt with in the District Court pertaining to control group members included sentencing and appeals. Expert opinion was used to estimate the number of court appearances required for an average appeal.

Penalty costs - Of the penalties allocated to control group members only those involving a direct cost to the government were costed. The cost of the penalties imposed was estimated by identifying which penalty was imposed and the duration of the penalty in days for each individual and then multiplying this by the per diem costs listed in Table 6. 


\section{Results}

\section{Outcomes}

Thirty-two subjects (one treated, 31 controls) were excluded from the analysis because they spent their entire follow-up period in custody. The sample sizes for analysing effectiveness were therefore reduced to 308 treated and 160 control subjects.

Compared with the control subjects, treated subjects were found to have significantly longer time to their first shop-stealing and their first drug offence (of any type). Figures 2 and 3 show the survival functions for these two offence types. For example, it can be seen from Figure 2 that 250 free days after referral to the Drug Court, an estimated 91 per cent of the treated group and 80 per cent of the control group had not yet committed a shop-stealing offence. The mean time to the first shop-stealing offence was 537 free days for the treated group and 469 free days for the control group. The mean time to the first drug offence was 544 free days for the treated group and 485 free days for the control group.

- Insert Figure 2 about here -

- Insert Figure 3 about here -

Table 5 shows the offending frequency results. Treated subjects had lower rates of offending for all offences except fraud, larceny other than shop-stealing, and motor vehicle theft. However, the differences were statistically significant only for the aggregate drug offence category.

- Insert Table 5 about here - 
Table 6 provides the costs of each of the components of the program for both treatment and control groups.

-Insert Table 6 about here -

The final costs for both the treatment and control groups are shown in Table 7. As well as the overall costs, the costs by treatment subgroup according to whether they were continuing, graduated or had been terminated from the program as of December 31, 2000 are included. The cost per day of the terminated group is more than double that of the graduated group reflecting the time these participants spent incarcerated (sanctions and post termination penalties). The graduated group incurred low corrective services costs, and, as their visits to the ADC decreased as they progressed through the program, these costs are also lower. For the purposes of calculating the ICER, the costs for the entire group were used.

The average costs per day (\$143 for treatment group, \$151 for the control group) were used in the cost effectiveness analysis. However, the average length of stay for the control group is less than the overall length of time for the treatment group.

- Insert Table 7 about here -

\section{COST EFFECTIVENESS}

The two offences used for each outcome measure were possess/use opiates and shopstealing. While it is recognised that these outcome measures do not incorporate a measure of health and/or well being of the participant, they do capture the extent of recidivism. Any change in the rate of re-offending was a crucial point of comparison between the ADC and the conventional courts. 
The incremental cost effectiveness equation is:

$I C E R=\left(C_{T}-C_{C}\right) /\left(N R_{T}-N R_{C}\right)$

where $\mathrm{C}=$ costs, $\mathrm{T}=$ treatment group, $\mathrm{c}=$ control group, $\mathrm{NR}=$ recidivism rate. Table 8 shows the costs and outcomes for each of the cost-effectiveness ratios calculated.

- Insert Table 8 about here -

The ICER 1 is $-\$ 0.17$. This can be interpreted as meaning that an additional $\$ 0.17$ is incurred to achieve an additional crime free day in the control group. The ICER 2, can be interpreted as meaning that it costs $\$ 1905.14$ more for the control group to prevent one additional drug related offence. While the results of the ICER 1 would suggest there are no differences between the two groups, ICER 2 may be interpreted as indicating that the ADC program is more cost effective than conventional sanctions in preventing additional drug-related offences.

\section{Uncertainty}

In economic evaluation, uncertainty is usually addressed in one of two ways.

Statistical or probabilistic analyses are used to address issues of sampling variation and parameter uncertainty. Where uncertainty exists about the methods or inputs used (e.g. in terms of prices or resource use), sensitivity analysis is the most common technique employed by economists to test the robustness of the assumptions.

In this study, since patient level data was not available for all aspects of the ADC program, statistical analysis was not possible. Therefore, sensitivity analysis was undertaken around some key inputs.

Insert Table 9 about here - 
The results presented in Table 9 are indicative of the findings of the sensitivity analyses. Only when the proportion of sentence served was varied (assuming that only $66 \%$ of the sentence was served) was the cost per day for the treatment group lower than the control group. This reinforces the results from the main study which suggest that costs for the control group are driven by the costs of enforcing penalties rather than court costs. Applying the same assumption to the treatment group also decreases the costs for this group reflecting the impact of penalties for those who were terminated from the ADC program.

\section{Discussion}

This study is the first assessment of the costs and cost-effectiveness of a drug court in Australia. The NSW ADC program is not a single, homogeneous service designed to deal with a defined problem shared by all receivers of the service. It is a complex intervention designed to benefit people with a range of different problems, all of which have resulted in drug dependence and drug-related crime. Such an intervention poses unique problems for evaluators \{Board, 2000 \#91;Coast, 2000 \#93;Godber, $1997 \# 86\}$.

Although this evaluation was conducted using the traditional steps of a costeffectiveness analysis (CEA), the complexity of the program and data limitations meant it was not always possible to adhere directly to the guidelines that are accepted as the gold standard ${ }^{(16)}$. We have compared our costing methods to a framework proposed by Graves ${ }^{(17)}$. Table 10 demonstrates both our attempts to follow such guidelines and maintain an acceptable standard but also depicts some of the pragmatic decisions required.

- Insert Table 10 about here - 
The costing perspective which informs this study was limited to the measurement of costs that could be called treatment costs within the ADC program and the control group. Thus, broader societal benefits that may flow from the ADC program such as reduced long-term demand for health and criminal justice services, reduced insurance claims, social security outlays and pain and suffering from criminal victimisation have not been included. Nor have potential societal costs such as public health costs that can arise due to imprisonment. Had it been possible to quantify these benefits and costs, the gap between the ADC and conventional sanctions in terms of costeffectiveness may well have been larger.

Data that would have facilitated more detailed inputs to the economic evaluation were often of poor quality or simply not available. For example, while a staff survey was used to apportion costs to various activities in the drug court; it was not possible to use this method to identify individual specific treatment or probation and parole activities and costs. Thus, a cost per drug court encounter was developed which reflected both frequency and type of visit but did not vary across individuals regarding their actual patterns of treatment. Lack of treatment data at an individual level also meant that the relative effectiveness of different treatment modalities within the ADC program could not be determined.

Some limitations also exist in relation to calculating the cost of sentencing for the control group and these costs probably represent a conservative estimate for the control group. In particular, the activity data used to calculate the sentencing costs in a Local court were based on a small sample of participants. Similarly, due to the lack of data for control group members sentenced in a District court, such costs were calculated using global financial data resulting in an average cost per person despite the fact that costs may have differed considerably across participants. Despite these 
issues, the sensitivity analysis demonstrated that varying the Court costs had little impact on the final results.

The results of this evaluation have a number of implications for policy. First, the cost-effectiveness of the NSW ADC has been and could be further improved ${ }^{(4)}$. One of the major cost drivers for both treatment and control groups is the cost of imprisonment. In the case of the control group this is hardly surprising, since the majority were imprisoned. In the ADC program imprisonment costs stem partly from the fact that prison is frequently used as a sanction for non-compliance with program conditions and partly due to the large number of participants who were terminated from the program and subsequently spent time in gaol. One important change made by the ADC has been to introduce suspended sanctions and permit participants to reduce these sanctions through good behaviour. This policy has reduced the number and frequency of offenders moving through the prison system which in turn reduces the cost of the ADC relative to conventional sanctions.

The effectiveness results suggest that those who remain on the ADC program commit significantly fewer offences and take longer to commit their first offence than either those rejected from the program or the control group ${ }^{(4)}$. This, combined with the cost results suggests that better targeting or earlier termination of those participants not progressing after a reasonable time may improve the cost-effectiveness of the program.

\section{Conclusion}

The results of this study reveal that, for the 23 month period of the evaluation, the ADC was as cost-effective as conventional sanctions in delaying the time to the first offence and more cost-effective in reducing the frequency of offending. Sensitivity analysis indicates that these conclusions are robust under a range of plausible variations in the parameter values that underpin the costing. The relative cost- 
effectiveness of the ADC is encouraging considering its highly experimental nature and the lack of experience in Australia in establishing and running ADC programs. It is all the more notable because, although there was no alternative to the use of official records to measure drug-related crime, changes in court appearance rates are arguably a fairly crude and insensitive measure of changes in criminal activity and the long term societal changes resulting from the use of an ADC-type program may be even more marked. 
Table 1: Criteria for acceptance into Drug Court

Under section 5 of the Act, in order to participate in the ADC trial an individual must:

- be charged with an offence under the jurisdictions of the Local and District courts, excluding charges of physical violence, sexual assault or drug trafficking;

- be dependent on illicit drugs;

- be willing to plead guilty to the offence with which they have been charged;

- be highly likely to be sentenced to full time imprisonment;

- be willing to participate in the Drug Court;

- be a resident of the area in which the ADC operates;

- and not be suffering from any mental condition that could prevent or restrict the person's active participation in the program 
Table 2: Classifications for resource use

\begin{tabular}{l|l}
\hline \multicolumn{1}{c|}{ Category } & \multicolumn{1}{c}{ Sub-category } \\
\hline Court & Administration, management and planning \\
& Court sitting \\
& Court facility and infrastructure costs \\
& Custodial/sheriff services \\
Initial referral/ assessment & - includes assessment by nurse, parole officers, legal aid \\
Assessment and detoxification & and police \\
& Incarceration between assessment and court appearance \\
& (where appropriate) \\
& Detoxification \\
& Clinical/pharmaceutical treatment/ residential \\
& rehabilitation \\
& Treatment plans and management, counselling \\
& Treatment infrastructure \\
& NSW Health Departmental support \\
& Urinalysis \\
& Participant monitoring - report backs, probation and parole \\
& Custodial sanctions \\
& Conventional gaol \\
& Non-custodial sentences \\
\hline
\end{tabular}


Table 3. Distribution of time by activity type

\begin{tabular}{lrrr}
\hline Type of activity & Court activity & $\begin{array}{c}\text { Client related (non- } \\
\text { court) }\end{array}$ & $\begin{array}{c}\text { Administration / } \\
\text { overhead }\end{array}$ \\
\hline Drug court team & $45 \%$ & $30 \%$ & $25 \%$ \\
Court reporter/ & $100 \%$ & $0 \%$ & $0 \%$ \\
attendant/ security & & & \\
Registry / overhead & $7 \%$ & $27 \%$ & $66 \%$ \\
\hline
\end{tabular}


Table 4. Appearances at Drug Court (Feb 1999 - December 2000)

\begin{tabular}{lrrr}
\hline Type of appearance & Frequency & $\begin{array}{c}\text { Average minutes } \\
\text { per appearances }\end{array}$ & $\begin{array}{c}\text { Total time } \\
\text { (minutes) }\end{array}$ \\
\hline Pre-Program & 1,787 & 10 & 17,870 \\
On program & 9,591 & 3 & 28,773 \\
Sentencing / termination & 470 & 25 & 11,750 \\
/graduations & & & \\
\hline
\end{tabular}




\begin{tabular}{lccc}
\hline & \multicolumn{2}{c}{$\begin{array}{c}\text { Average number of offences } \\
\text { per 365 free days }\end{array}$} & \\
\cline { 2 - 3 } Offence type & $\begin{array}{c}\text { Treated } \\
(n=308)\end{array}$ & $\begin{array}{c}\text { Control } \\
(n=160)\end{array}$ & $\begin{array}{c}p \text {-value } \\
\text { (Wilcoxon) }\end{array}$ \\
\hline Theft offence & 3.07 & 4.04 & 0.61 \\
Break enter \& steal & 0.35 & 0.78 & 0.70 \\
Fraud & 0.09 & 0.07 & 0.08 \\
Shop stealing & 0.22 & 0.80 & 0.12 \\
Other larceny & 1.26 & 1.24 & 0.70 \\
Unlawful possession & 0.45 & 0.70 & 0.62 \\
Motor vehicle theft & 0.70 & 0.44 & 0.37 \\
\hline Drug offence & 0.08 & 0.62 & 0.04 \\
Possess/use opiates & 0.04 & 0.19 & 0.11 \\
Possess/use cannabis & 0.02 & 0.36 & 0.62 \\
Possess/use other & 0.01 & 0.04 & 0.40 \\
drug & & & 0.70 \\
Deal/ traffic opiates & 0.01 & 0.03 &
\end{tabular}


Table 6: Summary Cost results

\begin{tabular}{|c|c|c|c|}
\hline Variable & Cost & Notes & Source of data \\
\hline Urine drug screen & $\$ 18.36$ & $\begin{array}{l}\text { Estimated from total costs and total number } \\
\text { of screens provided with cost }=\$ 25 \text {; } \\
\text { overestimated total expenditures }\end{array}$ & $\begin{array}{l}\text { Attorney General's } \\
\text { Department - for } \\
\text { expenditures } \\
\text { ADC data base for counts } \\
\text { of urine screens }\end{array}$ \\
\hline $\begin{array}{l}\text { Court - Pre program } \\
\text { appearance }\end{array}$ & $\$ 436.72$ & $\begin{array}{l}\text { Derived from ADC expenditure, staff } \\
\text { information, ADC data }\end{array}$ & $\begin{array}{l}\text { ADC expenditures ADC } \\
\text { data base for utilisation } \\
\text { Staff survey }\end{array}$ \\
\hline $\begin{array}{l}\text { Court - On program } \\
\text { appearance }\end{array}$ & $\$ 251.16$ & $\begin{array}{l}\text { Derived from ADC expenditure, staff } \\
\text { information, ADC data }\end{array}$ & $\begin{array}{l}\text { ADC expenditures } \\
\text { ADC data base for } \\
\text { utilisation } \\
\text { Staff survey }\end{array}$ \\
\hline $\begin{array}{l}\text { Court - Termination, } \\
\text { Graduation Sentencing or } \\
\text { appearance }\end{array}$ & $\$ 835.96$ & $\begin{array}{l}\text { Derived from ADC expenditures, staff } \\
\text { information, ADC data }\end{array}$ & $\begin{array}{l}\text { ADC expenditures } \\
\text { ADC data base for } \\
\text { utilisation } \\
\text { Staff survey }\end{array}$ \\
\hline $\begin{array}{l}\text { Cost per day in residential } \\
\text { rehabilitation }\end{array}$ & $\$ 100.00$ & & Health Department \\
\hline $\begin{array}{l}\text { Cost per available day in } \\
\text { treatment 1998/99 }\end{array}$ & $\$ 127.50$ & $\begin{array}{l}\text { Includes start-up costs } \\
\text { Based on all days available and all } \\
\text { treatment costs }\end{array}$ & $\begin{array}{l}\text { NSW Health, Area Health } \\
\text { Services }\end{array}$ \\
\hline $\begin{array}{l}\text { Cost per available day in } \\
\text { treatment } 1999 / 00\end{array}$ & $\$ 39.93$ & $\begin{array}{l}\text { Based on all days available and all } \\
\text { treatment costs }\end{array}$ & Health Department \\
\hline $\begin{array}{l}\text { Cost per available day in } \\
\text { treatment } 2000 / 01\end{array}$ & $\$ 23.85$ & $\begin{array}{l}\text { Based on all days available and all } \\
\text { treatment costs }\end{array}$ & Health Department \\
\hline $\begin{array}{l}\text { Cost per day in Detoxification } \\
- \text { men }\end{array}$ & $\$ 243.00$ & $\begin{array}{l}\text { Corrections Health costs and Marginal } \\
\text { costs from Corrective services }\end{array}$ & $\begin{array}{l}\text { Corrections Health, } \\
\text { Department of Corrective } \\
\text { Services }\end{array}$ \\
\hline $\begin{array}{l}\text { Cost per day in Detoxification } \\
\text { - women }\end{array}$ & $\$ 235.00$ & $\begin{array}{l}\text { Women's gaol per diem and daily cost of } \\
\text { CHS }\end{array}$ & $\begin{array}{l}\text { Corrective Health, } \\
\text { Department of Corrective } \\
\text { Services }\end{array}$ \\
\hline Correctional Centre & $\$ 119.63$ & Cost per diem & $\begin{array}{l}\text { Department Of Corrective } \\
\text { Services }\end{array}$ \\
\hline Male Gaol & $\$ 170.82$ & Cost per diem & $\begin{array}{l}\text { Department Of Corrective } \\
\text { Services }\end{array}$ \\
\hline Female Gaol & $\$ 223.03$ & Cost per diem & $\begin{array}{l}\text { Department of Corrective } \\
\text { Services }\end{array}$ \\
\hline $\begin{array}{l}\text { Corrections Health (not } \\
\text { Detoxification) }\end{array}$ & $\$ 12.04$ & Cost per diem & Corrections Health \\
\hline Community Service Orders & $\$ 2.63$ & Cost per diem & Probation and Parole \\
\hline Home Detention & $\$ 56.43$ & Home detention per diem & $\begin{array}{l}\text { Probation } \\
\text { and Parole }\end{array}$ \\
\hline $\begin{array}{l}\text { Recognizance (S.558) with } \\
\text { supervision of adult/probation } \\
\text { service }\end{array}$ & $\$ 3.01$ & Probation per diem & $\begin{array}{l}\text { Probation } \\
\text { and Parole }\end{array}$ \\
\hline $\begin{array}{l}\text { S.12 Suspended sentence with } \\
\text { supervision }\end{array}$ & $\$ 3.01$ & Probation per diem & Probation and Parole \\
\hline Sentencing Local Court & $\$ 200.34$ & $\begin{array}{l}\text { Average per person of sentence - all guilty } \\
\text { pleas, } 85 \% \text { Legal Aid (15\% no legal } \\
\text { representation), includes court and non- } \\
\text { court costs }\end{array}$ & $\begin{array}{l}\text { Attorney General's } \\
\text { Department, Drug Court, } \\
\text { Local Court }\end{array}$ \\
\hline
\end{tabular}


Table 7 Average cost and length of stay

\begin{tabular}{|c|c|c|c|c|}
\hline & \multicolumn{4}{|c|}{ Treatment Group } \\
\hline & $\begin{array}{c}\text { Continuing } \\
(\mathrm{n}=91)\end{array}$ & $\begin{array}{c}\text { Graduated } \\
(n=23)\end{array}$ & $\begin{array}{c}\text { Terminated } \\
(n=195)\end{array}$ & $\begin{array}{c}\text { All } \\
(n=309)\end{array}$ \\
\hline Average number of days & 365 & 511 & 238 & 304 \\
\hline \multirow[t]{2}{*}{ Average cost per day } & $\$ 115$ & $\$ 78$ & $\$ 188$ & $\$ 143 *$ \\
\hline & \multicolumn{4}{|c|}{ Control Group (n=138) } \\
\hline Average number of days & \multicolumn{4}{|c|}{234} \\
\hline Average cost per day & \multicolumn{4}{|c|}{$\$ 151^{*}$} \\
\hline
\end{tabular}


Table 8: Data for the cost effectiveness analysis

Treatment Group ( ${ }_{\mathrm{T}}$

Control group (c)

Cost per day (C)

$\$ 144$

$\$ 152$

Outcome 1. Mean time (days) to first

325.3

279.0

drug related offence (R)

Outcome 2. Average number of drug

0.008647

0.012770

related offences per day (R)

ICER 1

$\$ 0.17$

ICER 2

$\$ 1905$. 
Table 9: Sensitivity analyses

\begin{tabular}{|c|c|c|c|c|}
\hline Cost category & Group & Variation & Cost per day & $\begin{array}{c}\text { Percent difference } \\
\text { from original }\end{array}$ \\
\hline \multicolumn{2}{|l|}{ Treatment Group } & \multicolumn{3}{|c|}{$\$ 144$} \\
\hline \multirow[t]{4}{*}{ Urinalysis } & Treatment & $\begin{array}{l}\text { From } \$ 18 \text { per urine } \\
\text { screen to }\end{array}$ & & \\
\hline & & \$15 / screen & $\$ 144$ & $-0.26 \%$ \\
\hline & & \$35 / screen & $\$ 145$ & $1.3 \%$ \\
\hline & & $\$ 100$ /screen & $\$ 153$ & $6.4 \%$ \\
\hline Appearance costs & Treatment & Increased by $20 \%$ & $\$ 150$ & $4.2 \%$ \\
\hline Sentence & Treatment & $\begin{array}{l}\text { Assume only serve } \\
66 \% \text { of sentence }\end{array}$ & $\$ 127$ & $-11.6 \%$ \\
\hline \multicolumn{2}{|l|}{ Control Group } & \multicolumn{3}{|c|}{$\$ 152$} \\
\hline Appearance & Control & $\begin{array}{l}\text { Increase number of } \\
\text { appearances in LC by } \\
100 \%\end{array}$ & $\$ 152$ & $0.11 \%$ \\
\hline Sentence & Treatment & $\begin{array}{l}\text { Assume only serve } \\
66 \% \text { of sentence }\end{array}$ & $\$ 121$ & $-20.5 \%$ \\
\hline
\end{tabular}


Table 10 Comparison of the ideal costing methods with those used in the evaluation of the NSW ADC

\begin{tabular}{|c|c|}
\hline $\begin{array}{l}\text { Indicators of appropriate and } \\
\text { transparent costing methods* }\end{array}$ & $\begin{array}{l}\text { Economic evaluation of the NSW ADC } \\
\text { program }\end{array}$ \\
\hline $\begin{array}{l}\text { 1. Is the perspective of the cost } \\
\text { analysis stated explicitly? }\end{array}$ & $\begin{array}{l}\text { Yes, the perspective adopted was that of the client, } \\
\text { the NSW government. }\end{array}$ \\
\hline 2. Is the perspective adopted justified? & $\begin{array}{l}\text { While the evaluation adopted a government } \\
\text { perspective, it is recognised that there are } \\
\text { limitations to this choice. }\end{array}$ \\
\hline $\begin{array}{l}\text { 3. If } 1=\text { yes, were cost data included } \\
\text { that satisfied the stated perspective? }\end{array}$ & Yes, to the extent that the data allowed. \\
\hline $\begin{array}{l}\text { 4. Was a distinction made between } \\
\text { short and long run costs? Particularly } \\
\text { relevant if capital and other fixed costs } \\
\text { included in the cost estimate }\end{array}$ & $\begin{array}{l}\text { No due to the short time frame of the program and } \\
\text { evaluation. }\end{array}$ \\
\hline $\begin{array}{l}\text { 5. Were methods given for estimating } \\
\text { the quantities of resources (that } \\
\text { reflected variable costs) used by } \\
\text { subjects? }\end{array}$ & $\begin{array}{l}\text { This was the attempted however due to data } \\
\text { limitations not always possible, the implications } \\
\text { are discussed below. }\end{array}$ \\
\hline $\begin{array}{l}\text { 6. Were methods given for allocating } \\
\text { time of human resources (semi-fixed } \\
\text { costs) between subjects? }\end{array}$ & $\begin{array}{l}\text { Yes for the conventional court and ADC. Due to } \\
\text { data limitations this was not possible for the } \\
\text { treatment of addiction and corrective services. }\end{array}$ \\
\hline $\begin{array}{l}\text { 7. If relevant, were methods given for } \\
\text { allocating the use of other resources } \\
\text { (fixed costs) between subjects? }\end{array}$ & $\begin{array}{l}\text { Yes rental and overhead costs were apportioned to } \\
\text { individuals for both the conventional court and } \\
\text { ADC. Due to data limitations this was not } \\
\text { possible for the treatment of addiction and } \\
\text { corrective services. }\end{array}$ \\
\hline $\begin{array}{l}\text { 8. Were methods given for the } \\
\text { estimation of prices, unit costs or } \\
\text { charges (were they published, derived } \\
\text { by researchers, or estimated by a } \\
\text { finance department)? }\end{array}$ & $\begin{array}{l}\text { The estimates used in this study were a mixture of } \\
\text { derived unit costs and those estimated by } \\
\text { organisations involved in the ADC program. }\end{array}$ \\
\hline $\begin{array}{l}\text { 9. Were data other than hospital } \\
\text { charges or charges developed by third } \\
\text { party payers used? Expenditures or } \\
\text { charges do not always reflect } \\
\text { opportunity cost. }\end{array}$ & $\begin{array}{l}\text { A bottom up approach was used to estimate the } \\
\text { cost of conventional court system and the ADC } \\
\text { where possible. However, of necessity, per diem } \\
\text { charges were used for gaol costs. }\end{array}$ \\
\hline $\begin{array}{l}\text { 10. Was the year(s) reported in which } \\
\text { the costs data were collected? }\end{array}$ & Yes - $1998-2000$ \\
\hline
\end{tabular}


Figure 1

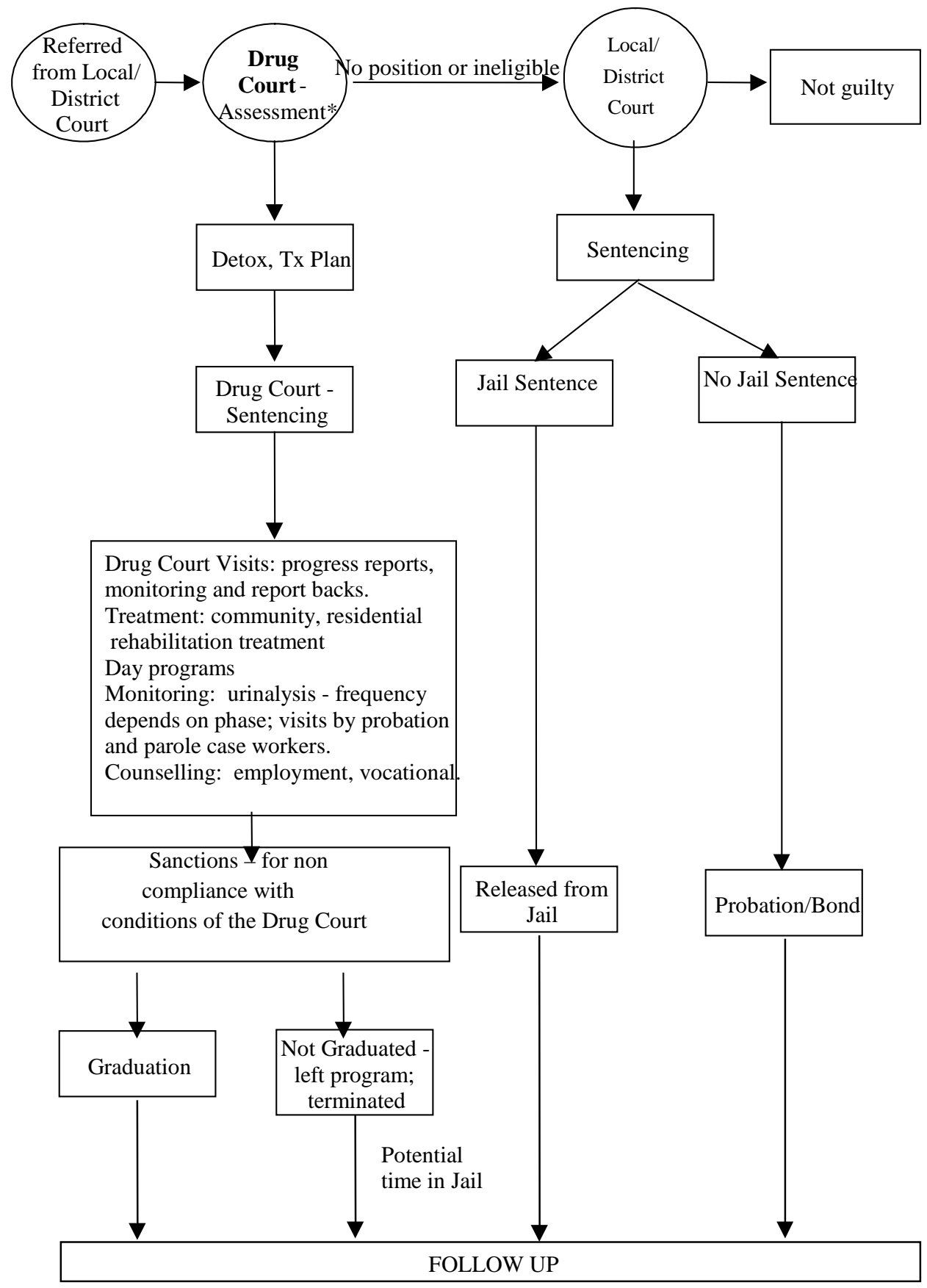


Figure 2: Time to first shop-stealing offence

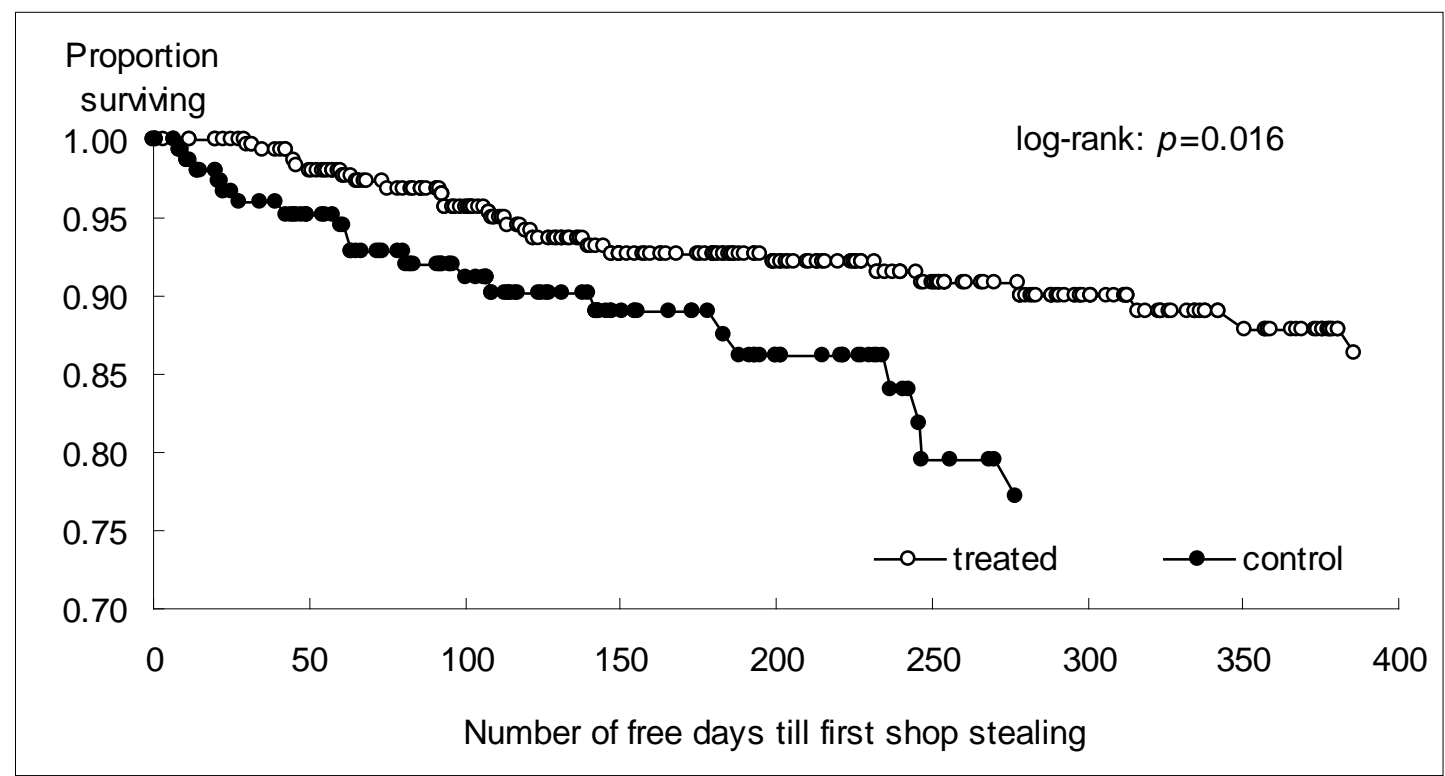


Figure 3: Time to first drug offence

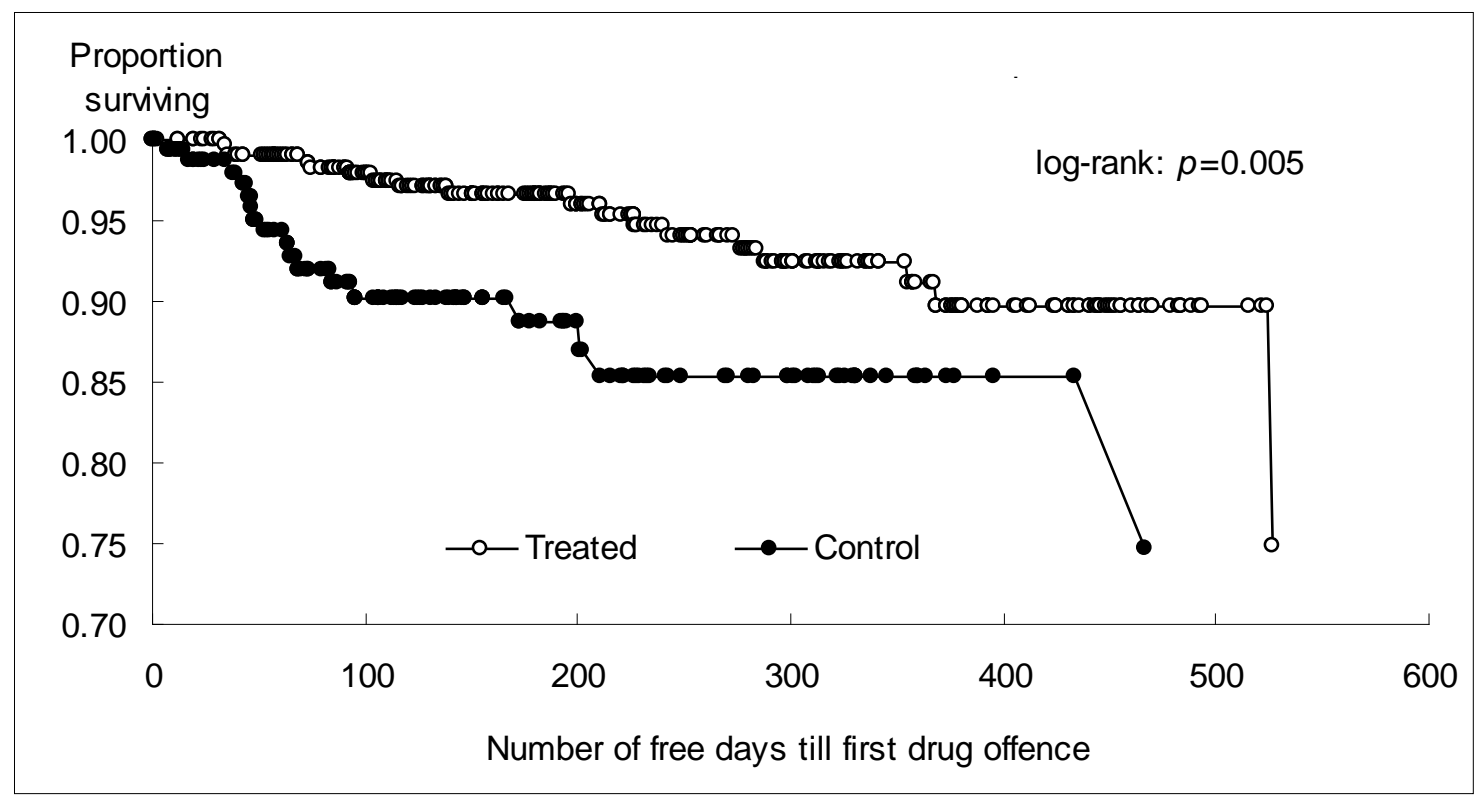




\section{References}

1. Justice. UDo. Defining Drug Courts: The Key Components. Report not a CHERE. Washington, DC.: US Department of Justice, Office of Justice Programs; 19971997.

2. United States General Accounting Office. Drug courts : overview of growth characteristics and results. Washington: United States General Accounting Office; 1997.

3. Hall W. The role of legal coercion in the treatment of offenders with alcohol and heroin problems. The Australian and New Zealand Journal of Criminology 1997;30(2):103-120.

4. Lind B, Weatherburn D, Chen S, Shanahan M, Lancsar E, Haas M, et al. New South Wales Drug Court Evaluation: Cost-Effectiveness Analysis. Sydney: NSW Bureau of Crime Statistics and Research; 2002 February 2002.

5. Breckenridge JF, Winfree LT, Maupin JR, Clason DL. Drunk Drivers, DWI "Drug Court", Treatment, and Recidivism, Who Fails?' Justice Research and Policy. 2000;2(1):87-105.

6. Deschenes EP, Turner S, W GP. Drug court or probation?: An experimental evaluation of Maricopa County's drug court. Justice System Journal 1995;18:55-73.

7. Peters RH, Murrin MR. Effectiveness of treatment-based drug courts in reducing criminal recidivism. Criminal Justice and Behavior 2000;27(1):72-96.

8. Spohn C, Piper RK, Martin T, Frenzel ED. Drug Courts and Recidivism: The Results of An Evaluation Using Two Comparison Groups and Multiple Indicators of Recidivism. Journal of Drug Issues 2001;31(1):149*476.

9. Belenko S, A FJ, Dumanovsky T. The effects of legal sanctions on recidivism in special drug courts. Justice System Journal 1994;17:53-81.

10. Belenko S. Research on drug courts : a critical review. National Drug Court Institute Review 1998;1(1):1-42.

11. Belenko S. Research on Drug Courts: A Critical Review 2001 Update: National Centre on Addiction and Substance Abuse, Columbia University.; 2001.

12. Makkai T. Trends \& issues in crime and criminal justice : Drug courts : issues and prospects. Canberra: Australian Institute of Criminology; 1998. Report No.: 95.

13. Frieberg A. Drug courts : some jurisprudential and sentencing issues. In; 2000.

14. Freeman K. New South Wales drug court evaluation: interim report on health and well-being of participants. Crime and Justice Bulletin 2001;53(February).

15. Freeman K, Lawrence Karski R, Doak P. New South Wales drug court evaluation : program and participation profiles. Crime and Justice Bulletin 2000;50(April):1-14.

16. Drummond M, O'Brien B, Stoddart G, Torrance G. Methods for the Economic Evaluation of Health Care Programmes. 2nd ed. Oxford: Oxford University Press; 1997. 
17. Graves N WD, Raine R, Hutchings A, Roberts J A,. Cost data for individual patients included in clinical studies: no amount of statistical analysis can compensate for inadequate costing methods. Health Economics Letters 2002;6(2). 